\title{
Analysis of the development path of radio, film and television culture in China
}

\author{
Weifu Liu \\ Xi'an International University, Xi'an Shaanxi, China, 710077 \\ Xi'an Jiaotong University Xi'an Shaanxi, China, 710049
}

Keywords: radio, film and television, cultural consciousness, cultureself confidence, cultural self strengthening.

\begin{abstract}
: radio, film and television culture consciousness and culture itself which is an inseparable strengthen the faith and culture whose consciousness of China's radio, film and television comes from culture. Confidence and cultural confidence will promote China's radio, film and television. Culture is more conscious neanwhile, the culture is stronger than Chinese broadcasting. according to culture differences, the introduction of category enhances people's learning of English. We must understand and set up correct culture learning motivation and correcting learning state in passive learning is active during our nation. Appropriately, joining culture exchange enriches leading circles, better for improving whole nation culture conscious. The purpose of film culture consciousness and cultural confidence is that the development of China's radio, film and television culture is great. The road to prosperity is bound to be cultural consciousness, self-confidence and road to self reliance.
\end{abstract}

\section{Enhancing cultural quality of Chinese radio, film and television by cultural consciousness}

For China's radio, film and television system, the so-called cultural consciousness, It refers to the enhancement of the initiative consciousness of China's radio, film and television culture promoted by leading awareness of radio, film and TV culture in China. On the development law and status of China's radio, film and television culture, throughout the scientific cognition and promotion of China's radio, film and television culture, we should play a conscious role in promoting historical responsibility. Cultural consciousness is further promoting the great development and prosperity of China's radio, film and television culture. In a sense, the prerequisites and the ideological foundation of this system are not to achieve cultural consciousness directly determines China's radio, film and television in the future and destiny of culture.

The cultural consciousness of China's radio, film and television system is concentrated on thinking. In recent years, the national radio, film and Television Department whose efforts should be made to strengthen ideological and cultural construction with ideological and cultural construction. Since reform and opening up, especially the beginning of the new century, China has been expanding its economy. Broadcasting and video products are showing more and more distinctive Chinese characteristics which is more outstanding the Chinese style and the significant it is. The Chinese style has become more and more important for the dissemination of foreign media. 
The new system of external communication in China is mainly manifested fast.

Enhance the cohesive force and combat effectiveness of the team and mobilize the national broadcast. To create the enthusiasm and creativity of film and television workers. More values on radio, film and television workers have consciously taken up the role of radio, film and television in the future and destiny of culture. To realize the social responsibility of China's dream drum and shout, this is the party and the people. The times entrusted by the people to the radio, film and television workers is the contemporary era. The professional pursuit of Chinese radio, film and television workers is belonging to the Chinese people. People share the important support of the Chinese dream.

\section{To highlight the cultural characteristics of China's radio, film and television with cultural self-confidence}

The Chinese nation is proud of its cultural confidence. The self-confidence and pride of national culture are persisted for long in history. In the middle of the historic river, we keep ourselves and absorb foreign elements, forming a unique Chinese character. Chinese excellent traditional culture. For Chinese radio, film and television system, cultural confidence is the fact that the scientific and correct concept of cultural development is further deduced, in short, a strong belief in China's radio, film and television. Full recognition and affirmation of value, and long-term accumulation of China form a strong relief to Chinese which is the pride and self-confidence of the vitality of excellent traditional culture, because of the firm belief in the fine traditional Chinese culture. according to culture differences, the introduction of category enhances people's learning of English. We must understand and set up correct culture learning motivation and correcting learning state in passive learning is active during our nation. Appropriately, joining culture exchange enriches leading circles, better for improving whole nation culture conscious. Since reform and opening up, especially the beginning of the new century, China has been expanding its economy. Broadcasting and video products are showing more and more distinctive Chinese characteristics which is more outstanding the Chinese style and the significant it is. The Chinese style has become more and more important for the dissemination of foreign media since reform and opening up, especially the beginning of the new century, China has been expanding its economy. Broadcasting and video products are showing more and more distinctive Chinese characteristics which is more outstanding the Chinese style and the significant it is. The Chinese style has become more and more important for the dissemination of foreign media.

The new system of external communication in China is mainly manifested in two aspects. Firstly, China's Radio and television products have been continuously landing overseas. Among them, CCTV and China Xinhua news, the audio and video programs of the TV network have basically achieved global coverage and at one hundred dozen countries and regions where have landed in China. Taiwan has also formed a global coverage of nearly one hundred countries and regions. There are two communication system where is in the overseas market share and influence of radio, film and television products. The number of exports continues to expand and quality continues to increase, for example, the domestic has exported some excellent cartoons to 17.The overseas box office and sales revenue of domestic films are also in the country and region increased year by year.

\section{To promote the prosperity of China's radio, film and television culture through cultural self-improvement}

For China's radio, film and television system, culture is self-improvement which is a core value of socialism with Chinese characteristics whose level of the department, high spirited, self transcendence, in order to enhance their cultural transmission power. And influence, and always 
maintain vigorous cultural vitality. The national radio, film and television workers has made unremitting efforts in the following five aspects. Further enhancing public opinion guidance ability.

In any country in the world, mainstream media are mainstream values. China's radio, film and television media must adhere to the party's management of media. Firstly, the value on the right leading road; secondly, the direction to culture constructtion; thirdly, path to renew people's culture consciousness.

\subsection{The value on the right leading road}

Culture is more conscious neanwhile, the culture is stronger than Chinese broadcasting. The Self -confidence comes from cultural self-confidence, and cultural self-confidence will promote China.

We must not hesitate to ensure correct guidance and effectively guide public opinion. opinion guidance ability. In any country in the world, mainstream media are mainstream values. China's radio, film and television media must adhere to the party's management of media.

\subsection{Secondly, the direction to culture construction}

Change the traditional methods and establish the new culture mode of the center culture. Under the traditional mode, ours are using the way of expressing, indoctrination which is often used in the our nation. It is difficult for people to learn in this way ot feel culture actively .To improve people initiative in learning a new culture to change the traditional methods and discard them. centered mode is based on values of nation. The center's culture tries to enrich activities and prepare various courses. The task is to enrich learning cuiture and activities to improve adapting the new ones. It is am important way to develop an initiative is to enable to learning from old culture which is passive.

\subsection{The culture system will not be of great significance}

Similarly, it is not advisable to evaluate the higher nation education system by evaluating the criteria of the economic system., Therefore, according to the requirements of different disciplines and different levels of culture, we must establish a scientific culture organization. According to the subject characteristics, aptitude and research interests of different people, and in accordance with the requirements of organizational goals, different standards should be implemented. Appraisal methods should not be all-inclusive. Apart from giving full play to the positive role of people in evaluation, nation should be appointed, promoted and appointed. Peer evaluation, especially off-campus peer evaluation, should play a very important role in the decision of term and the application of scientific research funds. Then the performance and post-related treatment and performance corresponding, so that talent selection, promotion and research funding is based on the acquisition of individual culture. On the basis of ability, we can bring up a kind of backward, pressure, dynamic and dynamic situation, stabilize and bring into playing the real culure cultivatioan.

The great role of talents ensures the good operation of university system and the formation of competitive advantages.

\section{Conclusion}

Chinese radio, film and television culture consciousness, cultural self-confidence and cultural which is strong and an indivisible. Confidence and cultural confidence will promote China's radio, film and television. Culture is more conscious neanwhile, the culture is stronger than Chinese broadcasting. At the same time, according to culture differences, the introduction of category 
enhances people's learning of English. We must understand and set up correct culture learning motivation and correcting learning state in passive learning is active during our nation. Appropriately, joining culture exchange enriches leading circles, better for improving whole nation culture conscious. According to the subject characteristics, aptitude and research interests of different people, and in accordance with the requirements of organizational goals, different standards should be implemented. Appraisal methods should not be all-inclusive. Apart from giving full play to the positive role of people in evaluation, nation should be appointed, promoted and appointed.

The Self -confidence comes from cultural self-confidence, and cultural self-confidence will promote China. Radio, film and television culture is more conscious. The purpose of film culture consciousness and cultural confidence is. China's radio, film and television culture is bound to flourish and flourish. IThere are two communication system where is in the overseas market share and influence of radio, film and television products. The number of exports continues to expand and quality continues to increase, for example, the domestic has exported some excellent cartoons to 17.The overseas box office and sales revenue of domestic films are also in the country and region increased year by year. It is a way of cultural consciousness, cultural confidence and cultural self strengthening. Making gooding use of the advantages of culture power should promote the comprehensive efficiency of the university management system and foster and enhance the core competitiveness of the University. Many values on radio, film and television workers who have consciously been engaged in radio, film and television in the future and destiny of culture. In oder to realize the social responsibility of China's dream drum and shout for which, this is the party and the people. The times entrusted by the people to the radio, film and television workers is the contemporary era.

\section{References}

[1] Fang Deyun's 60 years in New China: the status of a great power of radio and television[J]Journal of China Radio and television, 2009 (10)

[2] Lin Hui, China's mainstream media and the construction of mainstream values [J]. NEW Hearing and communication studies, 2008 (2)

[3] Development center of the State Administration of radio, film and television, 2010

[4] China Radio, film and television development report [M] Beijing: Xinhua PublishingSociety, 2010

[5] Qu Heng Chang the core competitiveness of advanced technology universities promotes the international competition of higher education in China [J].Competitive advantage "Comparative Education Research", second issue in 2015.

[6] Liu Yan: analysis of the current situation and characteristics of University Teachers' human resources, [J]. Huaihua University Newspaper, 2017 tenth issue.

[7] Li Yu's Analysis and reform of Jsalary management in Colleges and Universitie[J] Journal of Liaoning Institute of administration 083

[8] Li Ya Ya. Corpus linguistics in foreign language teaching Applied [J]. Shaanxi education, 2013

[9] Paul, editor in chief of S S Mayes, "knowledge management and organization" (JZhuhai publishing house, 98 edition, eighty-fourth pages. 2018.3

[10] Zhu Jingkun and Yao Yixin: the construction of a scientific academic management system and operational mechanism in Universities2015.6 